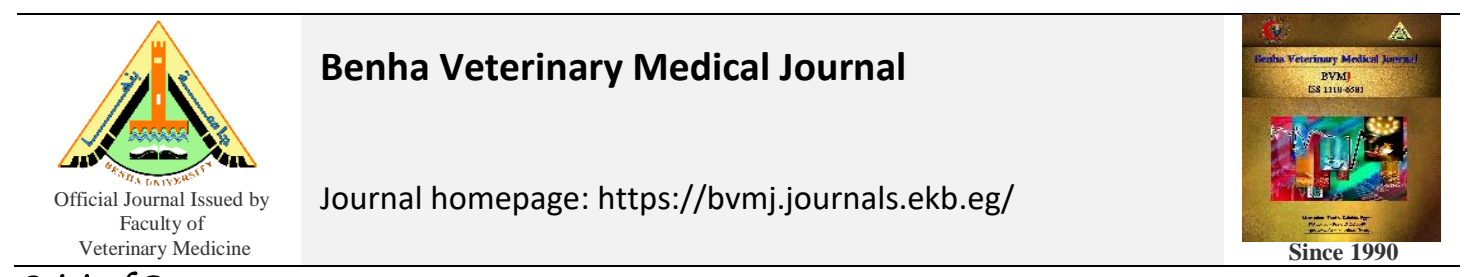

Original Paper

\title{
Assessment of organochlorine pesticides residues in tilapia fish (Oreochromis Niloticus)
}

S. R. Khalifa ${ }^{1}$, M. A. Hassan' ${ }^{2}$, R. A. Amin'2, N. M. Marzouk ${ }^{1}$

${ }^{1}$ Food Safety Reference Lab. Animal Health Research Institute. Dokki, Giza

${ }^{2}$ Department of Food Hygiene, Faculty of Veterinary Medicine, Benha University

\begin{tabular}{|c|c|}
\hline ARTICLE INFO & ABSTRACT \\
\hline $\begin{array}{l}\text { Keywords } \\
\text { Muscle tissue } \\
\text { Oreochromis niloticus } \\
\text { Organochlorine } \\
\text { Pesticides residues } \\
\text { Tilapia } \\
\text { Received } 18 / 02 / 2020 \\
\text { Accepted } 31 / 03 / 2020 \\
\text { Available On-Line } \\
\text { 18/07/2020 }\end{array}$ & $\begin{array}{l}\text { In the present study, Organochlorine pesticides (OCPs) residues were determined in muscle } \\
\text { tissues of Tilapia (Oreochromis niloticus) with different body weights collected randomly from } \\
\text { different regions at Cairo and Giza markets using Gas Chromatography. The total mean values } \\
\text { of DDT, DDD, DDE, Endrin, Dieldrin, Endosulfan, } \gamma \text {-chlordane, } \delta \text {-BHC, Heptachlor epoxide, } \\
\text { Methoxychlor and Heptachlor residues in the examined samples of tilapia were } 16.82 \pm 4.7 \text {, } \\
44.80 \pm 4.65,8.34 \pm 1.42,26.54 \pm 3.13,10.91 \pm 2.72,6.20 \pm 1.17,21.32 \pm 3.44,16.17 \pm 3.07 \text {, } \\
5.33 \pm 10.67,1.24 \pm 0.31 \text { and } 1.28 \pm 0.31 \mathrm{ppb} \text {, respectively. Accumulation of organochlorine } \\
\text { pesticides in fish tissues was related to rate of pollution, lipid content, feeding behavior, rate, } \\
\text { size and age. There were significant differences between organochlorine pesticides residues } \\
\text { and different weights of tilapia. Most of the examined samples were within the maximum } \\
\text { permissible limits of set by US-FDA (2008) and Codex Alimentarius Commission (1996). } \\
\text { Human health assessment risk was discussed, and consumption of these fish had no potential } \\
\text { hazard to human health as hazard ratio was less than one. }\end{array}$ \\
\hline
\end{tabular}

\section{INTRODUCTION}

Fish consumption has increased simultaneously with the growing interest of their nutritional and therapeutic benefits. Tilapia (Oreochromis niloticus) is the major fish species consumed in Egypt, due to its high nutritive value, palatability and relatively low price compared with other kinds of fishes (Morshdy et al., 2018). One of the major sources of human exposure to environmental contaminants could be consumption of contaminated fish (Yahia and Elsharkawy, 2014).

Organochlorine pesticides are classified as a class of the Persistence Organic pesticides depend on their toxicity, persistence, high lipid solubility, bioaccumulation nature and long-range transport potential (Luzardo et al., 2009) which tend to bio-concentration and bio-magnification in food chain (Neves Dias et al., 2015). Aquatic environment is contaminated with organochlorine pesticides through surface run off, discharge from surface, pesticides application, carless disposal of empty containers and equipment washings ( $\mathrm{Lu}$ et al., 2011).

Storage and elimination of pesticides from the fish depend on habitat, physiological factors, lipid content, feeding behavior, rate and routes of biotransformation of pesticides, species, size, age and sex of fish (Ribeiro et al., 2005). Pesticides concentration, time of exposure, toxicity of active ingredients and individual's health status are several factors for pesticide effects (Debnath and Khan, 2017). Organochlorine contaminants persist in the environment as they resist physical, chemical, biological and photochemical breakdown processes (Mrema et al., 2013). Reproductive failures and birth defects, endocrine disruptions, immune system malfunction and cancers are a health hazards of organochlorine pesticides (Afful et al., 2010). Exposure to organochlorine pesticides is associated with type 2 diabetes (Jayaraj et al., 2016). Organochlorine pesticides affect the nervous, immune, reproductive, renal and hepatic systems (Polder et al., 2014).

Therefore, this study was carried out to determine organochlorine pesticides residues in different weights of Tilapia (Oreochromis niloticus) and to compare the obtained results with the maximum permissible limits of US-FDA (2008) and Codex Alimentarius Commission (1996) and also evaluation of human health risk associated with fish consumption.

\section{MATERIAL AND METHODS}

\subsection{Collection of samples:}

One hundred random samples of tilapia fish (Oreochromis niloticus) were divided into 3 groups according to their weights (Group A: up to $200 \mathrm{gm}, \mathrm{n}=30$ ), (Group B: 200$400 \mathrm{gm}, \mathrm{n}=40$ ) and Group C: $400-600 \mathrm{gm}, \mathrm{n}=30$ ). They were collected from different localities at Cairo and Giza markets for determination of organochlorine pesticides residues in muscle tissues using Gas Chromatography.

\subsection{Sample preparation:-(AOAC, 1996).}

The soft parts of fish samples were removed. A muscle tissue sample $(50 \mathrm{gm})$ was taken from the dorsal muscle and prepared for extraction and clean up procedures at the same day of collection.

\footnotetext{
* Corresponding author: S. R. Khalifa, Food Safety Reference Lab. Animal Health Research Institute. Dokki, Giza
} 


\subsection{Extraction of OCP (AOAC, 1996).}

Fifty gm of the sample blending with $100 \mathrm{gm}$ anhydrous sodium sulphate and $150 \mathrm{ml}$ petroleum ether for $2 \mathrm{~min}$, poured through filter funnel into a suction flask and put in rotary evaporator till complete evaporation of petroleum ether and obtaining only fat content.

\subsection{Sample clean up and injection into $G C$ apparatus} (AOAC, 1996)

The obtained fat film from previous step was cleaned up by petroleum ether-acetonitrile partitioning and finally clean up by florisil column by eluting the obtained extract through the column 3 times at the same rate with $20 \mathrm{ml}$ of 6,15 and $50 \%$ diethyl ether in petroleum ether, respectively, and concentrate the eluate in rotary evaporator till obtaining a dry film which is then was dissolved in $2 \mathrm{ml} \mathrm{n}$-hexane and transferred to autosampler vials.

\subsection{Quantitative determination of organochlorine pesticides \\ The extracts were injected into gas chromatography} apparatus (Agilent, model 6890) equipped with a Ni63 electron capture detector, capillary column of $30 \mathrm{~m}$ length, $0.32 \mathrm{~mm}$ internal diameter, and $0.25 \mu \mathrm{m}$ film thickness. The oven temperature was programmed from an initial temperature $160{ }^{\circ} \mathrm{C}$ ( 2 min hold) to $280{ }^{\circ} \mathrm{C}$ at a rate of 5 ${ }^{\circ} \mathrm{C} / \mathrm{min}$ and maintained at $280{ }^{\circ} \mathrm{C}$ for $10 \mathrm{~min}$. Injector and detector temperatures were maintained at 280 and $320{ }^{\circ} \mathrm{C}$, respectively. Nitrogen was used as a carrier gas at flow rate of $4 \mathrm{ml} / \mathrm{min}$ and injection volume of $1 \mu \mathrm{l}$. The pesticide residues were identified based on comparison of relative retention times to those of known standards. The concentration of organochlorine pesticides was calculated from the following equation: Concentration (C) of a certain pesticides $(\mathrm{ppb})$

\footnotetext{
$\mathrm{C}=\frac{\text { peak area }(\text { sample }) \times \text { dilution }(2 \mathrm{ml}) \times \text { standard conc. }(\mathrm{ng})}{\text { peak area }(\text { standard }) \times \text { injection volume }(1 \mu \mathrm{l}) \times \text { sample weight }(\mathrm{gm})} \times 1000$

*Limit of Detection $(\mathrm{LOD})=0.001 \mathrm{ppb}$
}

\subsection{Human health risk assessment:}

It can be determined through the following parameters:

2.6.1. Estimated daily intake:

$\mathrm{EDI}=\mathrm{C} \times \mathrm{DR} / \mathrm{BW}(\mathrm{WHO}, 1987)$

Where: $\mathrm{C}$ is the concentration of the OCP $(\mathrm{mg} / \mathrm{kg})$ in raw fish, DR is the daily consumption of fish ( $\mathrm{Kg} /$ day) and BW is the average body weight set at $60 \mathrm{~kg}$ (WHO, 2010).

The estimated daily consumption rate in Egypt was conservatively set at $55.9 \mathrm{~g}$ /day per person in Cairo governorate (FAO, 2003).

\subsubsection{Carcinogenic Risk:}

Both cancer risk (CR) and hazard (HR) ratios were calculated according to $\mathrm{CR}=\mathrm{EDI} \times \mathrm{CSF}$ (USEPA, 2005)

Where CSF is cancer slope factor ( $\mathrm{mg} / \mathrm{kg}$ per day). Its value was 0.34 for $\Sigma \mathrm{DDT}, 0.35$ for $\Sigma \mathrm{CHL}, 1.6$ for HCB, 16 for dieldrin, 9.1 for heptachlor epoxide (USEPA, 2000).

If the CR is smaller than 10-4 is considered "Unacceptable risk", between 10-6 and 10-4 are considered "levels of concern" and CR more than 10-6 is considered" acceptable risk" (USEPA, 2005).

\subsubsection{The Hazard Ratios (HR):}

To evaluate the potential noncarcinogenic health risk, it was assessed by calculating the hazard index $(\mathrm{HI})$

$\mathrm{HI}=\mathrm{EDI} / \mathrm{ADI}$ (US EPA, 1991)

Where, EDI: Estimated Daily Intake ( $\mathrm{mg} / \mathrm{kg}$ bw) and ADI: Acceptable Daily Intake (mg/kg bw).

For a preliminary quantitative risk assessment, $\mathrm{HI} \leq 0.2$ is considered to indicate negligible adverse health effects as a result of exposure, while HI values exceeding this threshold require a further detailed risk assessment or risk management measures to be undertaken (Health Canada, 2004).

Hazard ratio (HR) was evaluated for carcinogenic effects, it was calculated using the following equation

HR=EDI/BMC (USEPA, 2005; Jiang et al., 2005):

Where the $\mathrm{BMC}$ is the benchmark concentration derived from the USEPA CSF: BMC $=($ Risk $\times$ BW $) /($ Fish consumption $\times \mathrm{CSF}$ ) Where the risk is set at one in a million chances for lifetime exposure, and fish consumption is the amount of fish consumed per day $(\mathrm{Kg} / \mathrm{d})$ relative to body weight $(\mathrm{kg})$. An HR greater than one indicates a potential risk to human health (Dougherty et al., 2000).

\subsection{Statistical analysis}

Data obtained from the current study was statistically analyzed by using the Statistical Package for the Social Sciences (SPSS) software (Corp, 2013). A value of P $<0.05$ was considered significant.

\section{RESULTS}

According to the results in table and figure (1) the organochlorine pesticides were:

(1) DDT: the total mean values of DDT in tilapia were $16.82 \pm 4.7 \mathrm{ppb}$. The mean values of DDT in tilapia at weights up to $200 \mathrm{gm}, 200-400 \mathrm{gm}$ and $400-600 \mathrm{gm}$ were ND, $6.64 \pm 1.28$ and $47.21 \pm 14.26 \mathrm{ppb}$, respectively. DDT was accepted in $100 \%$ of samples. There was high significant difference $(P<0.05)$ between different weights of tilapia.

(2) DDD: the total mean values of DDD in tilapia were $44.80 \pm 4.65 \mathrm{ppb}$. The mean values of DDT in tilapia at weights up to $200 \mathrm{gm}, 200-400 \mathrm{gm}$ and $400-600 \mathrm{gm}$ were $8.29 \pm 1.60,50.62 \pm 5.13$ and $73.54 \pm 10.97 \mathrm{ppb}$, respectively. DDT was accepted in $100 \%$ of samples. There was a high significant difference $(P<0.05)$ between different weights of tilapia.

(3) DDE: the total mean values of DDT in tilapia were $8.34 \pm 1.42 \mathrm{ppb}$. The mean values of DDE in tilapia at weights up to $200 \mathrm{gm}, 200-400 \mathrm{gm}$ and $400-600 \mathrm{gm}$ were $1.78 \pm 0.64$, $10.92 \pm 2.07$ and $11.46 \pm 3.57 \mathrm{ppb}$, respectively. DDE was accepted in $100 \%$ of samples. There was a high significant difference $(P<0.05)$ between different weights of tilapia.

(4) Endrin: the total mean values of Endrin in tilapia were $26.54 \pm 3.13 \mathrm{ppb}$. The mean values of Endrin in tilapia at weights up to $200 \mathrm{gm}, 200-400 \mathrm{gm}$ and $400-600 \mathrm{gm}$ were $1.55 \pm 0.41,24.05 \pm 3.04$ and $53.52 \pm 6.94 \mathrm{ppb}$, respectively. Endrin was accepted in $98 \%$ of samples. There was a high significant difference $(P<0.05)$ between different weights of tilapia.

(5) Dieldrin: the total mean values of dieldrin in tilapia were $10.91 \pm 2.72 \mathrm{ppb}$. The mean values of Dieldrin in tilapia at weights up to $200 \mathrm{gm}, 200-400 \mathrm{gm}$ and $400-600 \mathrm{gm}$ were $0.18 \pm 0.07,0.40 \pm 0.12$ and $35.66 \pm 7.33 \mathrm{ppb}$, respectively. Dieldrin was accepted in $100 \%$ of samples. There was a high 
significant difference $(P<0.05)$ between different weights of tilapia.

(6) Endosulfan: the total mean values of endosulfan in tilapia were $6.20 \pm 1.17 \mathrm{ppb}$. The mean values of Endosulfan in tilapia at weights up to $200 \mathrm{gm}, 200-400 \mathrm{gm}$ and 400-600 gm were $0.82 \pm 0.26,3.95 \pm 0.97$ and $14.57 \pm 3.20 \mathrm{ppb}$, respectively. Endosulfan was accepted in $100 \%$ of samples. There was a high significant difference $(P<0.05)$ between different weights of tilapia.

(7) $\gamma$-chlordane: the total mean values of $\gamma$-chlordane in tilapia were $21.32 \pm 3.44 \mathrm{ppb}$. The mean values of $\gamma$ chlordane in tilapia at weights up to $200 \mathrm{gm}, 200-400 \mathrm{gm}$ and $400-600 \mathrm{gm}$ were $0.25 \pm 0.08,17.56 \pm 3.82$ and $47.42 \pm 8.33 \mathrm{ppb}$, respectively. $\gamma$-chlordane was accepted in $100 \%$ of samples. There was a high significant difference $(P<0.05)$ between different weights of tilapia.

(8) $\delta$-BHC: the total mean values of $\delta$-BHC in tilapia were $16.17 \pm 3.07 \mathrm{ppb}$. The mean values of $\delta$-BHC in tilapia at weights up to $200 \mathrm{gm}, 200-400 \mathrm{gm}$ and $400-600 \mathrm{gm}$ were $2.82 \pm 0.59,7.09 \pm 1.44$ and $41.64 \pm 8.42 \mathrm{ppb}$, respectively. $\delta$ BHC was accepted in $100 \%$ of samples. There was a high significant difference $(P<0.05)$ between different weights of tilapia.

(9) Heptachlor-epoxide: the total mean values of Heptachlor-epoxide in tilapia were $5.33 \pm 10.67 \mathrm{ppb}$. The mean values of Heptachlor-epoxide in tilapia at weights up to $200 \mathrm{gm}, 200-400 \mathrm{gm}$ and $400-600 \mathrm{gm}$ were ND, $4.18 \pm 6.65$ and $12.19 \pm 5.79 \mathrm{ppb}$, respectively. Heptachlorepoxide was accepted in $100 \%$ of samples. There was a high significant difference $(P<0.05)$ between different weights of tilapia.

(10) Methoxychlor: the total mean values of Methoxychlor in tilapia were $1.24 \pm 0.31 \mathrm{ppb}$. Methoxychlor was not detected at weights up to $200 \mathrm{gm}$, and 400-600 gm. While, the mean values of Methoxychlor in tilapia at weight 200$400 \mathrm{gm}$ were $3.09 \pm 0.68 \mathrm{ppb}$. Methoxychlor was accepted in $100 \%$ of samples. There was a high significant difference $(P<0.05)$ between different weights of tilapia.

(11) Heptachlor: the total mean values of Heptachlor in tilapia were $1.28 \pm 0.31 \mathrm{ppb}$. Heptachlor was not detected at weights up to $400 \mathrm{gm}$, While, the mean values of Heptachlor in tilapia at weight $400-600 \mathrm{gm}$ were $4.27 \pm 0.82 \mathrm{ppb}$. Heptachlor was accepted in $100 \%$ of samples. There was a high significant difference $(P<0.05)$ between different weights of tilapia.

Table 1 Mean residue levels of organochlorine pesticides (ppb, wet weight) in Tilapia fish with different body weights

\begin{tabular}{|c|c|c|c|c|}
\hline $\begin{array}{l}\text { Compound } \\
\text { Name }\end{array}$ & $\begin{array}{c}\text { Group A } \\
\text { (Up to } 200 \\
\text { gm) } \\
(\mathrm{n}=30)\end{array}$ & $\begin{array}{c}\text { Group B } \\
(200- \\
400 \mathrm{gm}) \\
(\mathrm{n}=40)\end{array}$ & $\begin{array}{c}\text { Group C } \\
(400-600 \\
\text { gm) } \\
(n=30)\end{array}$ & $\begin{array}{c}\text { Total mean } \\
\text { values }\end{array}$ \\
\hline DDT & ND & $6.64 \pm 1.28^{\mathrm{b}}$ & $47.21 \pm 14.26^{\mathrm{a}}$ & $16.82 \pm 4.7$ \\
\hline DDD & $8.29 \pm 1.60^{c}$ & $50.62 \pm 5.13^{b}$ & $73.54 \pm 10.97^{\mathrm{a}}$ & $\begin{array}{c}44.80 \pm \\
4.65\end{array}$ \\
\hline DDE & $1.78 \pm 0.64^{\mathrm{b}}$ & $10.92 \pm 2.07^{\mathrm{a}}$ & $11.46 \pm 3.57^{\mathrm{a}}$ & $8.34 \pm 1.42$ \\
\hline Endrin & $1.55 \pm 0.41^{\mathrm{c}}$ & $24.05 \pm 3.04^{\mathrm{b}}$ & $53.52 \pm 6.94^{\mathrm{a}}$ & $\begin{array}{c}26.54 \pm \\
3.13\end{array}$ \\
\hline Dieldrin & $0.18 \pm 0.07^{b}$ & $0.40 \pm 0.12^{\mathrm{b}}$ & $35.66 \pm 7.33^{\mathrm{C}}$ & $\begin{array}{c}10.91 \pm \\
2.72\end{array}$ \\
\hline Endosulfan & $0.82 \pm 0.26^{b}$ & $3.95 \pm 0.97^{b}$ & $14.57 \pm 3.2^{\mathrm{c}}$ & $6.20 \pm 1.17$ \\
\hline$\gamma$-chlordane & $0.25 \pm 0.08^{c}$ & $17.56 \pm 3.82^{\mathrm{b}}$ & $47.42 \pm 8.33^{\mathrm{a}}$ & $\begin{array}{c}21.32 \pm \\
3.44\end{array}$ \\
\hline$\delta$-BHC & $2.82 \pm 0.59^{b}$ & $7.09 \pm 1.44^{\mathrm{b}}$ & $41.64 \pm 8.42^{\mathrm{a}}$ & $\begin{array}{c}16.17 \pm \\
3.07\end{array}$ \\
\hline $\begin{array}{l}\text { Heptachlor } \\
\text { epoxide }\end{array}$ & ND & $4.18 \pm 6.65^{\mathrm{b}}$ & $12.19 \pm 5.79^{\mathrm{a}}$ & $\begin{array}{c}5.33 \pm \\
10.67\end{array}$ \\
\hline Methoxychlor & ND & $3.09 \pm 0.68^{b}$ & ND & $1.24 \pm 0.31$ \\
\hline Heptachlor & ND & ND & $4.27 \pm 0.82^{\mathrm{a}}$ & $1.28 \pm 0.31$ \\
\hline
\end{tabular}

The acceptability of each OCPs residue are evaluated according to permissible limit in table (2).

Figure 1 Mean values of Organochlorine residues ( $\mathrm{ppm}=\mathrm{mg} / \mathrm{kg}$ wet weight) in Tilapia fish samples (Oreochromis niloticus) with different body weights

-group A $=$ group $\mathrm{B} \quad$ =group C

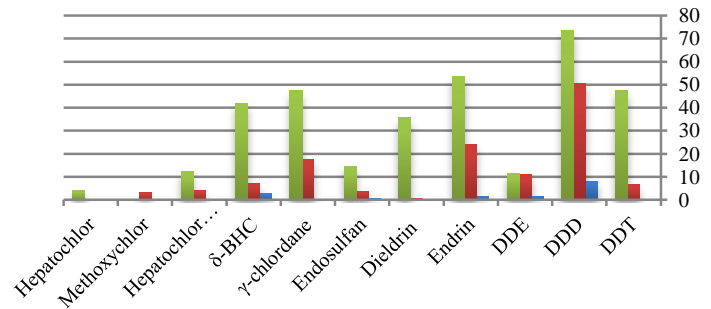

Table 2 The maximum permissible limits of organochlorine pesticides residues

\begin{tabular}{lc}
\hline Organochlorine pesticides & MRL (ppb) \\
\hline EDDTs & $5000^{\mathrm{b}}$ \\
Endrin & $100^{\mathrm{a}}$ \\
Aldrin +Dieldrin & $300^{\mathrm{b}}$ \\
Endosulfan & $100^{\mathrm{a}}$ \\
Gamma chlordane & $300^{\mathrm{b}}$ \\
Heptachlor + Heptachlor epoxide & $300^{\mathrm{b}}$ \\
Delta BHC & $300^{\mathrm{a}}$ \\
Methoxychlor & $300^{\mathrm{a}}$
\end{tabular}

MRL $=$ Maximum residue limit. $\mathrm{a}=$ Codex Alimentarius Commission (1996). $\mathrm{b}=$ US- FDA (2008)

\section{DISCUSSION}

Improper use of pesticide in agricultural production lead to pesticides or their metabolite residues in products which adversely affect aquatic life and human health (Acara et al., 2006). Organochlorine pesticides have long residual action and persist in the environment for long periods without losing their toxicity (Agbeve et al., 2014). Fish has a moderate ability to metabolize organochlorines so, contaminant loading in fish is well reflective of the state of pollution in surrounding environments (Guo et al.,2008).kidney problem, birth defects, impaired reproductive system, tumor development, cancer and death are adverse effects of Long-term exposure to pesticides (Debnath and Khan, 2017).

According to table (1) there were high significant differences between different weights of tilapia fish as large weight fish have more residues of organochlorines pesticides than small weight fish. Larger and/or fatty fish often contain higher organic contaminant concentrations than smaller and leaner fish (USEPA, 2000). Also, increase of organochlorine pesticides concentrations in large fish is explained by physiological changes resulting in their slow clearance(Olsson et al., 2000). Concentrations of OCPs vary among contaminants in ecosystems, different fish species, size classes within a fish species and fish tissues furthermore, chemical contaminants are not bioaccumulated to the same degree in all fish species (Hassan et al., 2020).

DDT, total mean value was $16.82 \pm 4.7 \mathrm{ppb}$. Lower findings were obtained by Morshdy et al. (2018) (12.5 $\pm 4.55 \mathrm{ppb}$, Ali et al. (2016) (0.064 $\pm 0.04 \mathrm{ppb})$ and Marzouk et al. (2016) $(4 \pm 0.8 \mathrm{ppb})$. Whereas, higher findings were obtained by Hassan et al. (2020) (154.1 ppb in Nile tilapia), Morshdy et al. (2018) (DDT in tilapia from Damietta and Sohag were 
$98.11 \pm 11.69$ and $21.33 \pm 5.12 \mathrm{ppb})$. Reproductive disorders, fetal anomalies and breast adenocarcinoma are positively related to DDT (Thompson et al., 2017).

DDD, total mean value was $44.80 \pm 4.65 \mathrm{ppb}$. Lower findings were recorded by Hassan et al. (2020) $(33.35 \pm 1.76 \mathrm{ppb}$ in Nile Tilapia), Hassanen et al. (2016) ( $30 \pm 2.3 \mathrm{ppb}$ of DDD from agricultural drainage), Kamel et al.(2015) (DDD in tilapia from Manzala Lake $0.087 \pm 0.008 \mathrm{ppb}$ ). Whereas, higher findings were obtained by Morshdy et al. (2018) (55.23 $\pm 7.11 \mathrm{ppb})$, Hassanen et al.(2016) (170 $\pm 21 \mathrm{ppb}$ DDD in $O$. niloticus from El-Ryiah El-Tawfiky). Moreover, Marzouk et al. (2016) ( $80 \pm 8 \mathrm{ppb}$ in Tilapia).

DDE, total mean value was $8.34 \pm 1.42 \mathrm{ppb}$. Lower findings were obtained by Hassan et al. (2020) $(6.27 \pm 0.68 \mathrm{ppb}$ in Nile Tilapia). Kamel et al. (2015) $(0.024 \pm 0.008 \mathrm{ppb}$ in tilapia from Manzala Lake). While, Yahia and Elsharkawy (2014) $(1.25 \pm 0.34 \mathrm{ppb}$ in Nile tilapia from Elwasta area). Also, Afful et al.(2010) $(0.6 \pm 0.01 \mathrm{ppb}$ in Tilapia from Weija along the Densu river in Ghana). Whereas, higher findings were reported by Morshdy et al. (2018) (44.15 $\pm 9.76 \mathrm{ppb}$ from Damietta). Mohamed et al. (2016) (95.55 $\pm 19.55 \mathrm{ppb})$, Talab and Ghannam (2015) (20 ppb in Nile tilapia from El-Kanater El-Khairia).

Total DDTs include DDT metabolites (sum of DDT, DDD and DDE). In the present study the mean values of total DDTs and its metabolites (DDT, DDD and DDE) were 69.96 $(16.82,44.80$ and $8.34 \mathrm{ppb})$ in tilapia fish. The obtained results were below permissible limits (5000 ppb) set by (USFDA, 2008). Degradation resistance and High lipid solubility of DDT residues and metabolites (DDD and DDE) make them soluble in fats and lipids of animals therefore, when water is contaminated, fish and other aquatic organisms have the capacity to absorb them from water and concentrate them in their fatty tissues (WHO, 2010). Also, DDT oxidize to DDE in aerobic or oxidation environment and deoxidize to DDD under anaerobic or reducing environment (Guo et al., 2008).

Endrin, total mean value was $26.54 \pm 3.13 \mathrm{ppb}$. Nearly Similar results were recorded by Hassan et al. (2020) $(25.02 \pm 0.01 \mathrm{ppb})$. while, Lower findings were obtained by Morshdy et al. (2018) (15.65 \pm 2.66 and $4.5 \pm 0.32 \mathrm{ppb}$ in tilapia from Damietta and Sohag) and Omwengna et al. (2016) determined $(0.04 \pm 0.05 \mathrm{ppb})$. Whereas, higher findings were obtained by Marzouk et al. (2016) $(100 \pm 0.3$ ppb). Abd El-Gawad and Abou El Ella (2014) (in Damietta branch was $124 \mathrm{ppb}$, while at Helwan location was 76.66 ppb). Also, Gad (2010) (The detected endrin from Helwan was 40 ppb, El-Giza 10 ppb and El- Qalubia 1600 ppb).

Dieldrin, total mean value was $10.91 \pm 2.72 \mathrm{ppb}$. Nearly similar results were obtained by El-Mekkawi et al. (2009) who monitored the mean concentrations of dialderin in three pools from Private Fish Farms residues in fish tissue from three pools in Private Fish Farms were (13.05, 9.7 and 4.2 $\mathrm{ppb}$, respectively). While, Lower findings were obtained by Hassan et al. (2020) (0.75 $\pm 0.13 \mathrm{ppb})$. Kuranchie-Mensah et al. (2011) (in Nile tilapia $4.09 \pm 0.65 \mathrm{ppb}$ ) and Daoud et al. (2011) $(0.16 \pm 0.006 \mathrm{ppb}$ in tilapia nilotica collected from Qena markets). Whereas, higher findings were recorded by Mohamed et al. (2016) $(41.51 \pm 0.58 \mathrm{ppb})$ and Talab and Ghannam (2015) (30 ppb in Nile tilapia from El-Kanater ElKhairia City). In the environment or the body of an organism, aldrin is converted into dieldrin by the action of sunlight and bacteria which is resistant to bacterial and chemical breakdown (Afful et al., 2013). Dieldrin is more environmentally persistent as it presents lower biotransformation and evaporation ratios than aldrin (Cetesb, 2008).

Endosulfan, total mean value was $6.2 \pm 1.17 \mathrm{ppb}$. Lower findings were recorded by Marzouk et al. (2016) (1.2 \pm 0.4 ppb) and Botaro et al. (2011) (in muscle of adult and juveniles farmed Nile tilapia $0.103 \pm 0.089$ and $0.033 \pm 0.026$ ppb). Also, Nasr et al. (2009) (3.836 ppb in El-Embaby drain at El Menofiya Governorate). Whereas, higher values were obtained by Hassan et al. (2020) (14.45 \pm 3.12$)$. Endosulfan remains in the environment for longer periods and bioaccumulates in plants and animals which leads to contamination of food consumed by humans (Brizet al., 2011). $\gamma$-chordane, total mean value was $21.32 \pm 3.44 \mathrm{ppb}$. Lower findings were obtained by Morshdy et al. (2018) (in tilapia from Damietta and Sohag were 16.44 \pm 1.22 and $10.1 \pm 2.78 \mathrm{ppb})$ and Nasr et al. (2009)(1.650 ppb in fish from El-Bagoria canal at El Menofiya Governorate). Whereas, Higher values were recorded by Hassanen et al.(2016)(in Oreochromis niloticus from Manzala Lake and El-Ryiah ElTawfiky were $90 \pm 11$ and $20 \pm 1.1 \mathrm{ppb}$ ).

Heptachlor epoxide, total mean value was $5.33 \mathrm{ppb}$. Nearly similar results were obtained by Nasr et al. (2009)(4.541 ppb in fish from Miet Rabiha drain at El Menofiya Governorate) which could be attributed to the drainage canal receives industrial and productive waste-waters. Lower findings were obtained by Kamel et al. (2015) $(0.113 \pm 0.052 \mathrm{ppb})$. Higher findings were obtained by Morshdy et al. (2018) (in tilapia from Damietta $14.33 \pm 2.11 \mathrm{ppb}$ ) and Talab and Ghannam (2015) (14 ppb in raw Nile tilapia fillets from local market at El-Kanater El-Khairia City). Levels of OCPs contaminants can vary significantly within the same fish species depending on the area where the fish was caught, the age and the fat content (Pandelova et al., 2008).

Methoxychlor, total mean value was $1.24 \pm 0.31 \mathrm{ppb}$. Higher findings were obtained by Hassan et al. (2020) $(6.98 \pm 1.88)$ and Morshdy et al. (2018) (in tilapia from Damietta and Sohag were $31.88 \pm 5.21$ and $8.55 \pm 2.12 \mathrm{ppb}$ ). the high ratio of OCPs in fish from Damietta may be because of the extensive past use of these OCPs in agricultural and nonagricultural activities (Azab et al., 2013).

Hepatochlor, total mean value was $1.28 \pm 0.31 \mathrm{ppb}$. similar values were obtained by Ogunfowokan et al. (2012) (the monthly mean values in fish in the rainy and dry season monthly were $1.36 \pm 1.00 \mathrm{ppb}$ and $1.89 \pm 1.75 \mathrm{ppb}$ ). Lower findings were obtained by Yahia and Elsharkawy (2014)(in Nile tilapia from Mankbad area $0.18 \pm 0.01 \mathrm{ppb}$ ). whereas, Higher findings were recorded by Hassan et al. (2020) (5.03 $\mathrm{ppb}$ ) and Morshdy et al. (2018) (in tilapia fish from Damietta $18.55 \pm 1.44 \mathrm{ppb}$ ). Whereas, Talab and Ghannam (2015) (in Nile tilapia from local market at El-Kanater El-Khairia City $15 \mathrm{ppb}$ ). While, too much high values were recorded by Abd El-Gawad and Abou El Ella (2014) measured Heptachlor residues at Kafr El-Zayat were $206.6 \mathrm{ppb}$ as industrial pesticide of Kafr El-Zayat pesticides Production Company. Pesticides end up in the tissue of aquatic organisms and bioaccumulate with time (Yahia and Elsharkawy, 2014). Many organochlorine pesticides and their metabolites are highly toxic and have been implicated in a wide range of adverse health effects such as cancer, neurological damage, reproductive system deformities, birth defect, and damage to the immune system (Leena et al., 2012). Children have higher values of cancer risks than adults from consumption of fish contaminated with organochlorine pesticides 
(Wenaty et al., 2019). Human health risk from consumption of fish tissue from different body weights groups (A, B and C): the EDI, CR and HR were estimated for fish groups with different weights. The obtained data in Table(3) showed that hazard ratio $(\mathrm{RH})$ of studied OCPs in fish of different weights was less than 1 that ensure consumption of these fish has no potential hazard risk to human health. Carcinogenic risk (CR) is considered acceptable risk (more than 10-6) for total DDT, dieldrin, $\gamma$-chlordane and $\delta$-BHC in group A and dieldrin, $\gamma$-chlordane in group $\mathrm{B}$ while $\mathrm{CR}$ is considered level of concern (between 10-6 and 10-4) for total DDT and $\delta$-BHC in group B,C and heptachlor epoxide in group B also, total heptachlor in group $\mathrm{C}$. whereas, Carcinogenic risk (CR) is considered non acceptable risk (less than 10-4) for dieldrin and heptachlor epoxide in group $\mathrm{C}$..

Table 3 Estimated daily intake (EDI) and Carcinogenic risk (CR) and Human risk (HR) of Organochlorine pesticides in fish groups (A, B and C) according to body weights

\begin{tabular}{|c|c|c|c|c|c|c|c|c|c|c|c|}
\hline & & & & EDI & & & CR & & & $\mathrm{HR}$ & \\
\hline OCPS & ADI & CSF & A & B & $\mathrm{C}$ & A & B & $\mathrm{C}$ & A & B & $\mathrm{C}$ \\
\hline Total DDT & 10000 & 0.34 & $9.38 \mathrm{E}-06$ & $6.35 \mathrm{E}-05$ & 0.0001 & 3.2E-06 & 2.2E- 05 & 4.2E- 05 & 0.00297 & 0.02013 & 0.0390 \\
\hline Dieldrin & 10000 & 16 & $1.67 \mathrm{E}-07$ & 3.73E-07 & 3.32E-05 & 2.7E-06 & $6 \mathrm{E}-06$ & 0.0005 & 0.0025 & 0.00556 & 0.4954 \\
\hline$\gamma$-chlordane & 500 & 0.35 & $2.33 \mathrm{E}-07$ & $1.63 \mathrm{E}-05$ & $4.42 \mathrm{E}-05$ & $8.2 \mathrm{E}-08$ & $5.7 \mathrm{E}-06$ & $1.5 \mathrm{E}-05$ & 7.6E-05 & 0.00534 & 0.0144 \\
\hline$\delta$-BHC & 100 & 1.6 & 2.63E-06 & $6.61 \mathrm{E}-06$ & 3.87E-05 & 4.2E-06 & $1.1 \mathrm{E}-05$ & $6.2 \mathrm{E}-05$ & 0.0039 & 0.00985 & 0.0579 \\
\hline Heptachlor epoxide & 5000 & 9.1 & ------- & $3.89 \mathrm{E}-06$ & $1.13 \mathrm{E}-05$ & ------ & $3.5 \mathrm{E}-05$ & 0.0001 & ------ & 0.03303 & 0.0963 \\
\hline Total Heptachlor & 100 & 4.5 & -------- & -------- & $1.53 \mathrm{E}-05$ & --------- & & $6.9 \mathrm{E}-05$ & --------- & ------- & 0.0643 \\
\hline
\end{tabular}

\section{CONCULSION}

From the present study, it could be concluded that there is a variation in the levels of organochlorine pesticides residues in the examined samples of tilapia fish at different body weights from different regions at Cairo and Giza markets. The large weight fish has more levels of organochlorine pesticides residues in its muscle tissue than small weight fish. So, the smaller fish is preferred than larger fish within a species as they may have lower contaminant levels, while the larger fish may be more contaminated because they had more time to accumulate residues in their bodies.

\section{REFERENCES}

1. Abd El-Gawad, H. A. and Abou El Ella, S. M (2014):Ecological Monitoring of Pesticide Residues and Algae Tolerating Organic Pollution. Nature and Science. 12(7):1-12.

2. Acara, A.; Ball, B.; Yeniova, M.; Aksu, P.; Düzgün, M. and Dağlı, S. (2006): Türkiye'ninkalıcı organic maddelere (pop'lar) ilişkin Stockholm UNIDO-POP'larprojesi, Proje no. GF/TUR/03/008.

3. Afful, S.; Anim. A. K. and Serfor-Armah, Y. (2010): Spectrum of Organochlorine Pesticide Residues in Fish Samples from the Densu Basin. Research Journal of Environmental and Earth Sciences 2(3): 133-138.

4. Afful, S.; Awudza, J. A. M.; Osae, S. and Twumasi S. K. (2013): Persistent Organochlorine Compounds in the Water and Sediment Samples from Lake Bosomtwe in Ghana. American Chemical Science Journal 3(4):434-448

5. Agbeve, S. K.; Osei-Fosu, P. and Carboo, D. (2014): Levels of organochlorine pesticide residues in Mondiawhitei, a medicinal plant used in traditional medicine for erectile dysfunction in Ghana. Int. J. Adv. Agric. Res. 1: 9-16.

6. Azab, M. M.; Darwish, A. A.; Mahmoud, H. A. and Sdeek, F. A. (2013): Residue levels of organochlorine pesticides in some ecosystem components of Manzala Lake. Environ Monit Assess. 185 (12): 10257-10268.

7. Ali, F. H. M.; Abdel-Attya, N. S.; Ouf, J. M. M. and Moustafa, M. A. S. (2016): Heavy metal residues in local and imported fish in Egypt. Journal of Veterinary Medical Research. 23 (1): $71-76$.

8. AOAC "Association Official Analytical Chemists" (1996): Official methods of the Association Official Analytical Chemists., Washington D.C.

9. Briz, V.; Molina-Molina, J. M.; Sánchez-Redondo, S.; Fernández, M. F.; Grimalt, J. O.; Olea, N.; Rodríguez-Farré, E. and Suñol, C. (2011): Differential estrogenic effects of the persistent organochlorine pesticides dieldrin, endosulfan and lindane in primary neuronal cultures. Toxicological Sciences. 120(2):413-27.

10. Botaro, D.; Torres, P. M.; Malm, O.; Rebelo, M. F.; Henkelmann, B. and Schramm, K. W. (2011): Organochlorine pesticides residues in feed and muscle of farmed Nile tilapia from Brazilian fish farms. Food and Chemical Toxicology. 49: $2125-2130$

11. Codex Alimentarius Commission (1996): Pesticides in food: Maximum Residue Limits, Extraneous Maximum Residue Limits.

12. Corp, IBM (2013): IBM SPSS statistics for windows version 22.0. Armonk, NY: International Business Machines Corp.

13. Daoud, J. R.; Hegazy, H. M. R. and Ahmed, A. M. (2011):Pesticide Residues in Frozen Beef and Fresh Tilapia (Oreochromis Niloticus) Displayed in Qena Governorate Markets. Journal of South Valley University for Environmental Researches. 1 (1), 1-7

14. Dougherty, C. P.; Holtz, S. H.; Reinert, J. C.; Panyocosit, L.; Axelrad, D. A. and Woodruff, T. J. (2000): Dietary exposures to food contaminants across the United States. Environmental Research. 84:170- 185 .

15. Debnath, M. and Khan, M. S. (2017): Health concerns of pesticides. In Pesticide Residue in Foods (pp. 103118). Cham: Springer International Publishing.

16. El Nabawi, A. G.; Heinzow, B. and Kruse, H. (1987): As, Cd, $\mathrm{Cu}, \mathrm{Pb}, \mathrm{Hg}$ and $\mathrm{Zn}$ in Fish from the Alexandria Region, Egypt. Bulletin of Environmental Contamination and Toxicology, 39, 889-896.

17. El-Mekkawi, H.; Diab, M.;Zaki, M. and Hassan, A. (2009): Determination of chlorinated organic pesticide residues in water, sediments and fish from private fish farms at Abbassa and Sahl Al-Husainia, SharkiaGovernorate. Aus. J. Basic Appl. Sci., 3(4): 4376-4383.

18. FAO (2003):Nutrition country profiles- Egypt. Rome, Italy August 2003

19. Gad, N. S. (2010): Organochlorine pesticides and trace metals contamination in some marketable fish in Egypt. Egyptian Journal of Aquatic Research, 36(4), 633-642

20. Guo, Y.; Meng, X. Z.; Tang, H. L. and Zeng, E. Y. (2008) Tissue distribution of organochlorine pesticides in fish collected from the Pearl River delta, China: Implications for fishery input source and bioaccumulation. Environ. Pollut., 155: $150-156$.

21. Hassan, M. A. E.; Ahmed, A. M.; Marzouk, N. M. andMaky, M. A. (2020): Detection of Organochlorine Pesticides Residues in Nile Fish and Its Risks in Qena City. SVUInternational Journal of Veterinary Sciences. 3 (1): 51-65. 
22. Hassanen, F. S.; Kamel, E. A.; Gaafar-Rehab, A. M.; Shaheen, A. A. (2016): Effect of grilling on pesticides residues in $O$. niloticus muscles. Benha Veterinary Medical Journal. 30 (1):348-357.

23. Health Canada (2004): Federal contaminated site risk assessment in Canada: Part1: Guidance on human health preliminary quantitative risk assessment (PQRA).

24. Jayaraj, R.; MEGHA, P. and SREEDEV, P. (2016): Organochlorine pesticides, their toxic effects on living organisms and their fate in the environment. Interdiscip Toxicol. 9 (3-4): 90-100.

25. Jiang, Q. T.; Lee, T. K.; Chen, K.; Wong, H. L.; Zheng, J. S.; Giesy, J. P.; Lo, K. K.; Yamashita, N.; Lam, P. K. (2005): Human health risk assessment of organochlorines associated with fish consumption in a coastal city in China. Environmental Pollution. 136: 155-165.

26. Kamel, E.; Moussa, S.; Abonorag, M. and konuk, M. (2015): Occurrence and possible fate of organochlorine pesticide residues at Manzala Lake in Egypt as a model study. Environmental Monitoring and Assessment. 187: 4161-4171.

27. Kuranchie-Mensah, H.; Palm, L. M. N.; Manukure, S. A.; Afful, S.; Adjei-Martey, G. and Arthur, J. K. (2011): Assessment of organochlorine pesticides and polychlorinated biphenyls levels in fishes from the Volta lake, Ghana and their suitability for human consumption. Elixir Food Science. 41: 5982-5990

28. Leena, S.; Choudhary, S. K. and Singh, P. K. (2012): Pesticide concentration in water and sediment of River Ganga at selected sites in middle Ganga plain. Int. J. Environ. Sci. 3(1):260-274.

29. Lu, L. C.; Wang, C. I. and Sye, W. F. (2011): Applications of chitosan beads and porous crab shell powder for the removal of 17 organochlorine pesticides (OCPs) in water solution Carbohydr. Polym., 83 (4): 1984-1989.

30. Luzardo, O. P.; Mahtani, V.; Troyano, J. M.; Alvarez de la Rosa, M.; Padilla-Pérez, A. I. , Zumbado, M.; Almeida, M.; Burillo-Putze, G.; Boada, C. and Boada, L. D. (2009): Determinants of organochlorine levels detectable in the amniotic fluid of women from Tenerife Island (Canary Islands, Spain) Environ. Res., 109 (5): 607-613

31. Marzouk, N. M.; Shoukry, H. M.; Ali, H.; Naser, G. A. and Fayed, A. M. Sh. (2016): Detection of Harmful Residues in Some Fish Species Egypt. J. Chem. Environ. Health. 2 (2):363-381.

32. Mohamed, A. A. R.; Tharwat, A. E. and Khalifa, H.A. (2016) Estimation of organochlorine pesticides and heavy metal residues in two species of mostly consumed fish in Sharkia Governorate, Egypt. Japanese Journal of Veterinary Research. 64(2): 233-241

33. Morshdy, A. E. M. A.; Darwish, W. S.; Daoud, J. R. M.; M A.M. Hussein, M. A. M. and Sebak, M. A. M. (2018): Monitoring of organochlorine pesticide residues in Oreochromis Niloticus collected from some localities in Egypt. Slov. Vet. Res. 55 (20): 303-311.

34. Mrema, E. J.; Rubino, F. M.; Brambilla, G.; Moretto, A. Tsatsakis, A. M. and Colosio, C. (2013): Persistent organochlorinated pesticides and mechanisms of their toxicity. Toxicology, 307: 7488

35. Nasr, I. N.; Arief, M. H.; Abdel-Aleem, A. H and Malhat, F. M. (2009): Persistent Organic Pollutants (POPs) in Egyptian Aquatic Environment. Journal of Applied Sciences Research, 5(11): 1929-1940.

36. Neves Dias, A.; Simão, V.; Merib, J. and E. Carasek, E. (2015): Use of green coating (cork) in solid-phase micro extraction for the determination of organochlorine pesticides in water by gas chromatography-electron capture detection. Talanta, 134 (1): 409-414.
37. Ogunfowokan, A. O.; Oyekunle, J. A. O.; Torto, N. and Akanni, M. S. (2012): organochlorine pesticide residues in fish tissues and water from an agricultural fish pond. Emir. J. Food Agric. 24 (2): 165-184.

38. Olsson, A.;Valters, K. and Burreau, S. (2000): Concentration of Organochlorine Substances in Relation to Fish Size and Trophic Position: A Study on Perch (Percafluviatilis L.).Environ. Sci. Technol. 34 (23): 48784886.

39. Omwenga, I.; Kanja, L.; Nguta, J.; Mbaria, J. and Patrick Irungu, I. (2016): Organochlorine pesticide residues in farmed fish in Machakos and Kiambu counties, Kenya. Cogent. Environmental Science. 2: 1-9.

40. Pandelova, M.; Henkelmann, B.; Roots, O.; Simm, M.; Järv, L.; Benfenati, E.; Schramm, K. W. (2008): Levels of PCDD/F and dioxin-like PCB in Baltic fish of different age and gender. Chemosphere, 71: 369-378

41. Polder, A.; Muller, M. B.; Lyche, J. L.; Mdegela, R. H.; Nonga, H. E.; Mabiki, F. P.; Mbise, T. J.; Skaare, J. U.; Sandvik, M.; Skjerve, E. and Lie, E. (2014): Levels and patterns of persistent organic pollutants (POPs) in tilapia (Oreochromis sp) from four different lakes in Tanzania: Geographical differences and implications for human health. Science of the Total Environment 488(489): 252-260.

42. Ribeiro, C; Vollaire, Y; Sanchez-Chardi, A. and Roche, H. (2005): Bioaccumulation and the effects of organochlorine pesticides, PAH and heavy metals in the Eel (Anguilla anguilla) at the Camargue Nature Reserve, France. Aquatic Toxicology. 74(1): 53-69.

43. Talab, A. S. and Ghannam, H. E. (2015): Organochlorine pesticide residues in raw and cooked fish fillets. Journal of Biodiversity and Environmental Sciences.7: 292-303.

44. Thompson, L. A.; Darwish, W. S.; Ikenaka, Y.; Nakayama, S M.; Mizukawa, H. and Ishizuka, M. (2017): Organochlorine pesticide contamination of foods in Africa: incidence and public health significance. J. Vet. Med. Sci.79 (4): 751-64.

45. US.FDA (U.S. Department of Health and Human Services, Food and Drug Administration) (2008): Pesticide chemical residues in food enforcement criteria (CPG 7141.01). Draft Guidance, January 2008.

46. USEPA United States Environmental Protection Agency (1991): Risk Assessment Guidance for Superfund Volume 1: Human Health Evaluation Manual (Part B), Development of Risk-Based Preliminary Remediation Goals (No. EPA/540/R92/003).

47. USEPA United States Environmental Protection Agency (2000): Guidance for assessing chemical contaminant data for use in fish advisories volume 2 risk assessment and fish consumption limits third edition.

48. USEPA United States Environmental Protection Agency (2005): Guidelines for carcinogen risk assessment.

49. Wenaty, A.; Fromberg, A.; Mabiki, F.; Chove, B.; Dalsgaard, A. Mdegela, R. (2019): Persistent Organochlorine Compounds Levels in Selected Fish Species from Lake Victoria and Associated Human Health Risks. Agriculture, Forestry and Fisheries. 8(1): 1-9

50. WHO (World Health Organisation) (1987): Evaluation of Certain Food Additives and Contaminants (Technical Report No. 751). Cambridge University Press.

51. WHO (World Health Organization) (2010): Inventory of IPCS and other WHO pesticide evaluations and summary of toxicological evaluations performed by the Joint Meeting on Pesticide Residues (JMPRs).

52. Yahia, D. and Elsharkawy, E. E. (2014): Multi pesticide and PCB residues in Nile tilapia and catfish in Assiut city, Egypt. Sci Total Environ. 466-467: 306-314. 